\title{
CHARACTERIZATION OF INCLUSION COMPLEXES BETWEEN BIFONAZOLE AND DIFFERENT CYCLODEXTRINS IN SOLID AND SOLUTION STATE
}

\author{
Hajnal Kelemen ${ }^{1}$, Angella Csillag ${ }^{1}$, Gabriel Hancu ${ }^{1 *}$, Blanka Székely-Szentmiklósi ${ }^{1}$, Ibolya Fülöpp ${ }^{2}$, \\ Erzsébet Varga ${ }^{3}$, Lavinia Grama ${ }^{4}$, Gábor Orgován ${ }^{5}$ \\ ${ }^{1}$ University of Medicine and Pharmacy of Târgu Mureş, Faculty of Pharmacy, \\ Department of Pharmaceutical Chemistry, Gh. Marinescu 38, 540139, Târgu Mureş, Romania \\ ${ }^{2}$ University of Medicine and Pharmacy of Târgu Mureş, Faculty of Pharmacy, \\ Department of Toxicology and Biopharmacy, Gh. Marinescu 38, 540139, Târgu Mureş, Romania \\ ${ }^{3}$ University of Medicine and Pharmacy of Târgu Mureş, Faculty of Pharmacy, \\ Department of Pharmacognosy and Phytotherapy, Gh. Marinescu 38, 540139, Târgu Mureş, Romania \\ ${ }^{4}$ University of Medicine and Pharmacy of Târgu Mureş, Faculty of Pharmacy, \\ Department of General and Inorganic Chemistry, Gh. Marinescu 38, 540139, Târgu Mureş, Romania \\ ${ }^{5}$ Research Group of Drugs of Abuse and Doping Agents, Department of Pharmaceutical Chemistry, \\ Hungarian Academy of Sciences, Semmelweis University, Högyes Endre u. 9, Budapest 1092, Hungary \\ gabriel.hancu@umftgm.ro
}

The aim of this study is to confirm the formation of inclusion complexes between bifonazole (BFZ) and different cyclodextrin (CD) derivatives. BFZ, an imidazole antifungal derivative, is a very hydrophobic compound, which is a major drawback in obtaining topical pharmaceutical formulations with optimal bioavailability. CDs may increase local drug delivery by enhancing the drug release and/or permeation. Several native and derivatized CD derivatives were tested in the experiments. The binary systems between BFZ and CDs were prepared in two molar ratios by physical mixing methods. The physicochemical properties of these complexes were studied by differential scanning calorimetry (DSC), Fourier transform infrared (FTIR) spectroscopy, and nuclear magnetic resonance (NMR) spectroscopy methods. The results showed favorable molecular interaction between the components in solid state and in solution. ${ }^{1} \mathrm{H}$ NMR-CD titrations and molecular modeling study showed that the most stable complex was obtained when using $\gamma$-CD. The Job's method and 2D NMR spectroscopy support the $2: 1$ stoichiometry of the BFZ : $\gamma$-CD complex.

Keywords: bifonazole; cyclodextrins; differential scanning calorimetry; Fourier transform infrared spectroscopy; ${ }^{1} \mathrm{H}$ NMR-CD titrations

\section{КАРАКТЕРИЗАЦИЈА НА ИНКЛУЗИОНИ КОМПЛЕКСИ МЕЃУ БИФОНАЗОЛ И РАЗЛИЧНИ ЦИКЛОДЕКСТРИНИ ВО ЦВРСТА СОСТОЈБА И ВО РАСТВОР}

Целта на ова истражување е да се потврди образувањето на инклузиони комплекси меѓу бифоназол (BFZ) и различни циклодекстрински (CD) деривати. BFZ, кој претставува имидазолски фунгициден дериват, е силно хидрофобно соединение, што претставува голем недостаток при добивање топични фармацевтски препарати со оптимална биорасположливост. CD може да ја зголеми локалната испорака на лекот со подобрување на ослободувањето и/или пропустливоста на лекот. Експериментално беа тестирани неколку нативни и дериватизирани CD. Бинарните системи меѓу BFZ и CD беа подготвени во два моларни односа со методи на физичко мешање. Физичкохемиските својства на овие комплекси беа испитувани со диференцијална скенирачка калориметрија (DSC), Фуриеова трансформна инфрацрвена (FTIR) спектроскопија и со нуклеарномагнетни резонантни спектроскопски методи. Резултатите покажуваат позитивна молекулска интеракција меѓу компонентите во цврста фаза и во раствор. Титрациите на ${ }^{1} \mathrm{H}$ NMR-CD и испитувањето со молекулско моделирање покажуваат дека најстабилен комплекс се добива со 
употреба на $\gamma$-CD. Методот на Job и 2D NMR спектроскопија ја потврдуваат 2:1 стехиометријата на комплексот BFZ : $\gamma$-CD.

Клучни зборови: бифоназол; циклодекстрини; диференцијална скенирачка калориметрија; Фуриеова трансформна инфрацрвена спектроскопија; ${ }^{1} \mathrm{H}$ NMR-CD титрации

\section{INTRODUCTION}

Bifonazole (BFZ) ((RS)-1-[phenyl(4-phenylphenyl)methyl]-1H-imidazole) (Fig. 1) is a substituted imidazole antifungal agent that is structurally related to other drugs from the azole group. It possesses a broad spectrum of activity in vitro against dermatophytes, molds, yeasts, dimorphic fungi, and some Gram-positive bacteria [1]. It has a double mechanism of action as it works by preventing the 14- $\alpha$-demethylation of 24-methylenedihydrolanosterol, consequently preventing the formation of the cellular membrane by inhibiting the production of ergosterol, and also causes direct damage to the membrane [2]. It also shows an antiinflammatory effect on erythema caused by histamine $[3,4]$. BFZ is available as $1 \%$ topical cream, powder, spray and lotion [5].

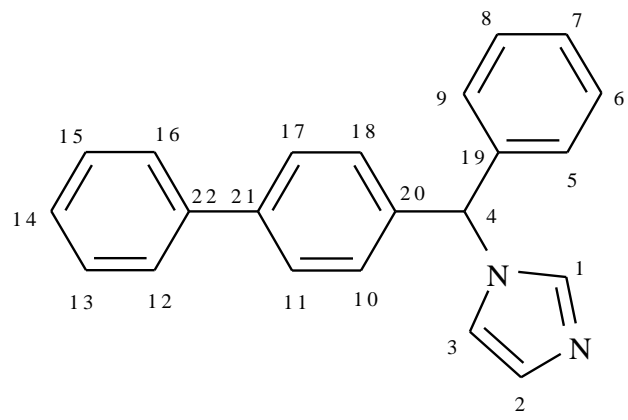

Fig. 1. Constitutional formula and atom numbering of BFZ

The therapeutic effectiveness of a drug depends on its bioavailability and ultimately on the solubility of the drug molecule. Usually only solubilized molecules can be absorbed by the cellular membrane to reach the specific site of drug action. Due to the imidazole cycle, BFZ is a basic compound (pKa 9.30), and due to the presence of the aromatic rings it is a lipophilic substance $(\log \mathrm{P}$ 4.77) which is almost insoluble in water. BFZ has a water solubility of $0.7 \mu \mathrm{g} / \mathrm{ml}$ at $25{ }^{\circ} \mathrm{C}$ [6].

Solubility is one of the most important parameters for achieving a suitable concentration of drug in the systemic circulation to obtain an appropriate pharmacological response. To overcome this problem, various formulation strategies can be applied to increase the dissolution characteristics, such as solid dispersion, micronization, salt for- mation, liquid-solid techniques, self-nanoemulsifying drug delivery systems and cyclodextrin (CD) complexation $[7,8]$.

CDs are a family of cyclic oligosaccharides consisting of 6,7 , or 8 glucopyranose units, corresponding to $\alpha-, \beta-$, and $\gamma$-CDs respectively, with a hydrophilic outer surface and a lipophilic central cavity, used as complexing agents to increase the aqueous solubility of poorly soluble drugs and to increase their bioavailability and stability. The introduction of hydrophobic moieties on the primary or secondary faces of native CDs gives them an amphiphilic character, enhances their inclusion capacity, and modifies their physicochemical properties. The concept of amphiphilic CDs is based on modulation of the hydrophobic/hydrophilic balance of their construction and modulation of their selfassembly properties through grafting of single or multiple substituents on the primary, secondary, or both faces of native CDs. Due to these features, CDs are able to form water-soluble inclusion complexes with many poorly soluble lipophilic drugs [9-12].

The formation of CD complexes is an equilibrium process where free "guest" molecules are in equilibrium with molecules in the complex [13]. In aqueous solution, the apolar CD cavity is occupied by water molecules which are energetically unstable, and therefore can be substituted by appropriate guest molecules, forming inclusion complexes [14-16]. The experimental methodology for the evaluation of the inclusion complexation of amphiphilic drugs with CDs includes the determination of association equilibrium constants for the inclusion process $[17,18]$.

Thermoanalytical techniques (differential scanning calorimetry, DSC; thermogravimetry) are frequently used in the investigation of the thermal properties of CDs and their inclusion complexes $[19,20]$.

In previously published articles, inclusion complexes of azole derivatives with CDs in aqueous solution and in the solid phase were studied by solubility methods, spectroscopy, thermal analysis, and X-ray diffractometry, and their modes of interaction were assessed. The importance of the hydrophobicity of the guest molecule and the spatial relationship between host and guest molecules were clearly reflected in the magnitude of the stability constant of the inclusion complexes [21, 22]. 
A nuclear magnetic resonance (NMR) spectroscopic study was published in order to evaluate the complexation of fluconazole with $\beta-\mathrm{CD}$, and the results confirmed the formation of an inclusion complex in aqueous solution [23, 24]. Complexes of BFZ and miconazole prepared with different $\mathrm{CDs}$ by various methods such as kneading, co-evaporation, and physical mixing were characterized by Fourier transform infrared spectroscopy (FTIR) and DSC studies, and the effect of complexationon the dissolution rate of BFZ was studied $[25,26]$.

The purpose of this study is to evaluate the possibility of interaction of the antifungal drug BFZ through complexation with different types of CDs. Binary system of BFZ and different CDs were prepared in two molar ratios, $1: 1$ and $2: 1$ (BFZ : CD), using the physical mixing method.

The resulting complexes were characterized by means of DSC thermal analysis, FTIR, NMR spectroscopy $\left({ }^{1} \mathrm{H}-\mathrm{NMR}\right)$ and molecular modeling.

To determinate the complex stability and stoichiometry, ${ }^{1} \mathrm{H}-\mathrm{NMR}-\mathrm{CD}$ titrations were carried out. The stoichiometry of the complexes was confirmed by the Job's method of continuous variation [27]. To explore the geometry of the inclusion complex, 2D COSY spectra were recorded [28].

\section{EXPERIMENTAL}

\subsection{Materials}

BFZ of pharmaceutical grade was acquired from Richter Gedeon (Târgu Mureș, Romania); $\mathrm{D}_{2} \mathrm{O}$ was purchased from Sigma-Aldrich (Germany). All the $\mathrm{CD}$ derivatives were acquired from Cyclolab Ltd (Budapest, Hungary). The following CDs were used in this study: $\alpha-, \beta-$, and $\gamma$-CDs, randomly methylated- $\alpha$-CD (RAME- $\alpha$-CD), randomly methylated- $\beta$-CD (RAMEB), randomly methylated- $\gamma$-CD (RAME $\gamma-C D)$, hydroxypropyl- $\beta-C D$ (HP $\beta-\mathrm{CD})$, hydroxypropyl- $\gamma$-CD (HP $\gamma-\mathrm{CD})$, sulfobutyl ether- $\alpha-\mathrm{CD}$ (SBE- $\alpha-\mathrm{CD})$, sulfobutyl ether- $\beta-\mathrm{CD}$ $(\mathrm{SBE}-\beta-\mathrm{CD})$, and sulfate- $\beta-\mathrm{CD}$ (S- $\beta-\mathrm{CD})$. Other chemicals of analytical grade were obtained from commercial suppliers and used without further purification. Ultrapure water produced using a Milli-Q system (Millipore, USA) was used in all experiments.

\subsection{Methods}

\subsubsection{Differential scanning calorimetry}

The temperature and enthalpy measurements were performed using a Mettler Toledo DSC 823e Thermal Analysis system (Schwerzenbach, Switzerland). Approximately 1-2 mg of the active ma- terial or binary systems was examined in aluminum pans between 25 and $400{ }^{\circ} \mathrm{C}$ in a nitrogen atmosphere with a flow rate of $50 \mathrm{ml} / \mathrm{min}$. The heating rate was $10{ }^{\circ} \mathrm{C} / \mathrm{min}$.

\subsubsection{Fourier-transform infrared spectroscopy}

FTIR analysis allowed the detection of inclusion complexation because the diffraction and infrared (IR) spectra patterns of the complex must be clearly distinct from those resulting from the super imposition of individual diffraction and IR spectra patterns. The IR spectra of BFZ, different $\mathrm{CD}$ derivatives, and their binary systems were recorded using an FTIR 470 Plus, (AbleJasco, Japan) spectrometer. The resolution was $4 \mathrm{~cm}^{-1}$, the wave number range was $2000-400 \mathrm{~cm}^{-1}$, and the scan number was 64 . The samples were embedded in $\mathrm{KBr}$ pellets. Analyses were performed at room temperature.

\subsubsection{Nuclear Magnetic resonance $\left({ }^{1} H-N M R\right)$ spectroscopy}

NMR spectroscopy has been recognized as an important tool for the interaction study of $\mathrm{CD}$ and pharmaceutical compounds in solution state. This technique also gives information on the topology of the interaction between analyte and CDs, not only furnishing information on the structure of inclusion complexes but also allowing the stoichiometry and association or binding constant of guest : CD complexes to be derived [29]. 2D COSY and ROESY experiments are important in CD-related studies, as they complement each other; COSY provides information on the coupling of protons, while 2D ROESY gives the same information through space [30].

To determine the complex stoichiometry and stability, ${ }^{1} \mathrm{H}-\mathrm{NMR}-\mathrm{CD}$ titrations were carried out. The stoichiometry of the complexes was evaluated by Job's method of continuous variation [31].

\subsubsection{1. ${ }^{l} H$-NMR-CD-titrations}

All measurements were effectuated on a Varian VNMR spectrometer $\left(600 \mathrm{MHz}\right.$ for $\left.{ }^{1} \mathrm{H}\right)$. Spectra were recorded at $25^{\circ} \mathrm{C}$ and referenced to internal $\mathrm{Na}$-acetate. Titrations were carried out in a medium at $\mathrm{pH} 2.0$, which was reached with a buffer solution containing $0.1 \mathrm{M} \mathrm{HCl}, 0.05 \mathrm{M} \mathrm{KCl}$, and $500 \mu \mathrm{l}$ $\mathrm{D}_{2} \mathrm{O}$. A stock solution containing $0.01 \mathrm{M} \mathrm{BFZ}$ was prepared in water and methanol and $1 \mathrm{mg}$ of Naacetate was added. The stock for the CDs was 0.015 $\mathrm{M}$. Next, $30 \mu \mathrm{l}$ of the BFZ stock solution was mixed with different volumes of $\mathrm{CD}$ stock solution, the 
appropriate background media were added to give a total volume of $600 \mu \mathrm{l}$, and ${ }^{1} \mathrm{H}-\mathrm{NMR}$ spectra were recorded. Solvent signals were suppressed with the water excitation technique (WET) sequence.

\subsubsection{Determination of complex stoichiometry}

Solutions were prepared from BFZ and the CDs with concentrations of $2 \mathrm{mM}$ in $5 \mathrm{v} / \mathrm{v} \%$ methanol and the medium at $\mathrm{pH} 2.0$, respectively. The solutions were mixed in different ratios. After that, ${ }^{1} \mathrm{H}-\mathrm{NMR}$ spectra were recorded, which were referenced to internal dimethyl sulfoxide (DMSO).

\subsubsection{Determination of the structure of inclusion complexes formed}

Solutions containing $5 \mathrm{mM} \mathrm{BFZ} \mathrm{and} 2.5$ $\mathrm{mM} \mathrm{CD}$ in methanol were examined. The structures of the complexes were determined with $2 \mathrm{D}$ COSY experiments.

\subsubsection{Molecular modeling studies}

Molecular modeling studies were performed using HyperChem 8.0 software (HyperChem (TM) Professional 8.0, Hypercube Inc., USA). BFZ, the $\mathrm{CDs}$, and the complexes were geometrically optimized using the molecular mechanics method
(MM+ force field, Polak-Ribiere algorithm, RMS gradient $\leq 0.01$ ). One or two molecules of $\mathrm{BFZ}$ were put manually into the cavity of each $C D$ with the phenyl or imidazole rings inside and the complexes were optimized geometrically using the same parameters as described before.

The formation energy $(E)$ was calculated with the formula:

$$
E=E_{\text {complex }}-\left(E_{C D}+E_{\text {bifonazole }}\right)
$$

where $E_{\text {complex }}, E_{\mathrm{CD}}$, and $E_{\text {bifonazole }}$ represent the minimum energy of the complexes, the CDs, and BFZ, respectively. Negative formation energy shows a thermodynamically favored complex; the most stable conformation is indicated by the higher formation energy [32, 33].

\section{RESULTS AND DISCUSSION}

\subsection{Differential scanning calorimetry}

Differences in the thermal behavior of BFZ, BFZ-CDs, and the corresponding inclusion complexes were evident. As shown in Figure 2, BFZ exhibits a characteristic endothermic fusion peak at $152.47^{\circ} \mathrm{C}$ corresponding to the $\mathrm{BFZ}$ melting point.
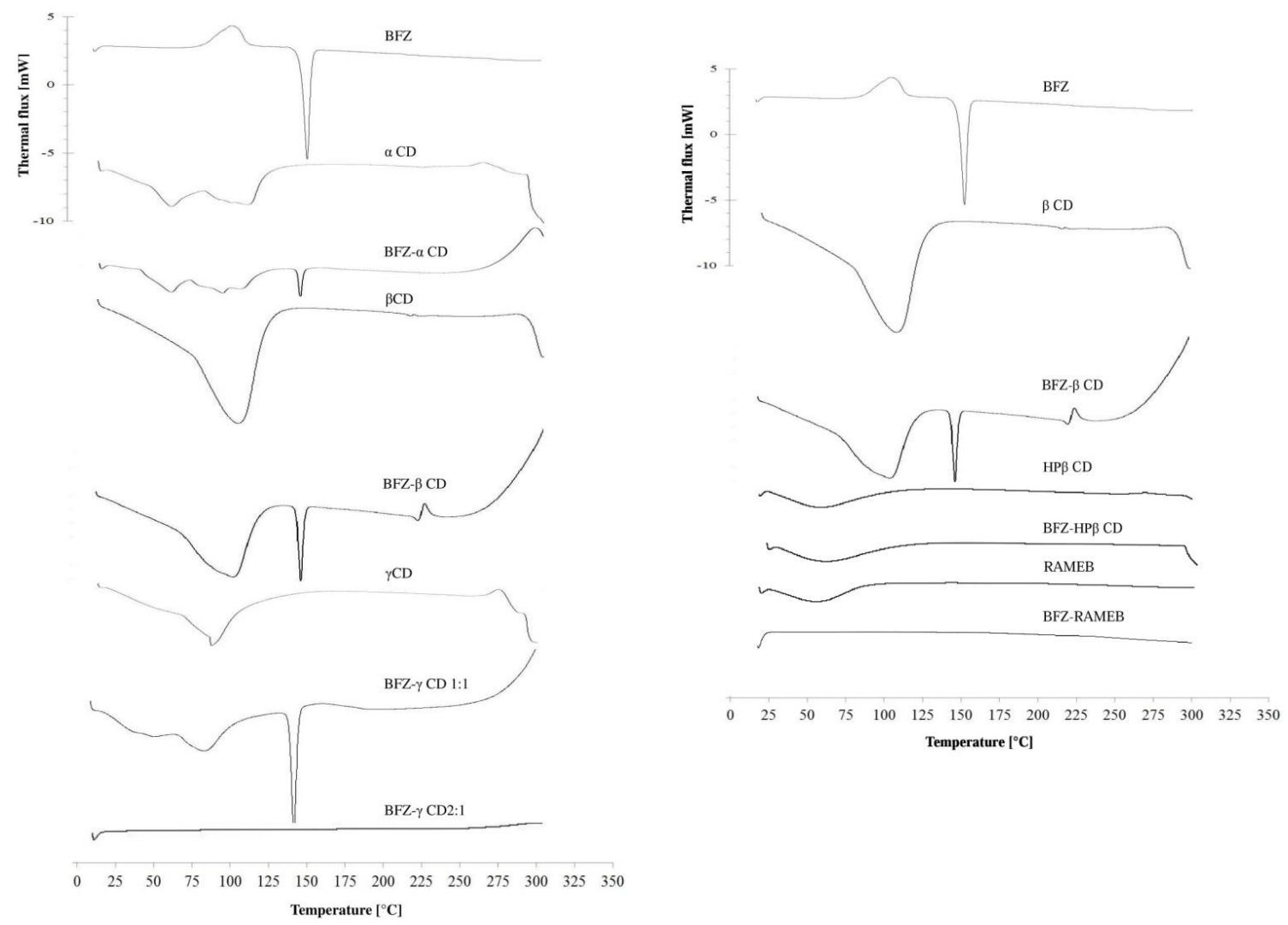

Fig. 2. DSC thermograms of BFZ, CDs, and complexes 
Furthermore, $\beta-\mathrm{CD}, \gamma-\mathrm{CD}, \mathrm{HP}-\beta-\mathrm{CD}$, and RAMEB show broad endothermic events in the range from 30 to $95{ }^{\circ} \mathrm{C}$, which are related to the loss of adsorbed water, and small endo- or exoeffects at $210-325{ }^{\circ} \mathrm{C}$ due to thermal degradation. DSC thermograms of the physical mixture for BFZ and $\alpha-\beta$, and $\gamma$-CDs show the existence of the endothermic peak of BFZ, indicating interactions between the CDs and BFZ. The BFZ peak in the physical mixture with $\gamma-\mathrm{CD}$ is increased, indicating a more intense interaction of BFZ with $\gamma$-CD. The DSC thermograms of BFZ- $\gamma-C D$ 2:1 complexes show the disappearance of the BFZ endothermic peak at $152.47{ }^{\circ} \mathrm{C}$. In the binary systems of BFZ with RAMEB and HP- $\beta-C D$, the complete disappearance of the BFZ endothermic peak can be observed, indicating a more intense interaction of BFZ with RAMEB or HP- $\beta-C D$. The absence of the characteristic peak of the drug is strong evidence for the inclusion of the drug in the CD cavity. This could be attributed to the formation of an amorphous solid dispersion, to the molecular encapsulation of the drug into the $\mathrm{CD}$ cavity, or both.

\subsection{Fourier transform infrared spectroscopy}

The FTIR spectra of BFZ presented in Figure 3 reveal numerous absorption bands in the fingerprint region.

The most intense peaks in the spectrum of $\mathrm{BFZ}$ are due to the imidazole ring $\left(1000-650 \mathrm{~cm}^{-1}\right.$, $1680-1640 \mathrm{~cm}^{-1}$ ) and the relationship between aliphatic carbon and $\mathrm{N}$ of the imidazole cycle $(\mathrm{CN}$ stretch), but the characteristic aromatic cycles can also be observed $\left(1600-1585 \mathrm{~cm}^{-1}\right)$.

Amongst the characteristic bands are 2850 $3000 \mathrm{~cm}^{-1} \mathrm{C}-\mathrm{H}$ bonds in the imidazole ring and three aromatic rings (Fig. 3).

In the spectrum of $\beta-\mathrm{CD}$ there is a wide absorption band in the $1200-1000 \mathrm{~cm}^{-1}$ area, attributed to the glucopyranosic ring. Another broad and strong absorption band in the $3000 \mathrm{~cm}^{-1}$ domain is attributed to $\mathrm{OH}$ stretching. For the binary systems, the $1600-600 \mathrm{~cm}^{-1}$ domain was chosen to highlight the modification of spectra due to complexation. Having a photo- protective character, CDs mask the characteristic peaks of groups that are included in their cavities.

The presence of the imidazole ring in the frequency characteristics of the absorption spectrum of the complex in the $1000-650 \mathrm{~cm}^{-1}$ range and assigned to the link between the carbon atom of the imidazole ring and $\mathrm{N}$ in the 1200-1070 $\mathrm{cm}^{-1}$ range indicates that this ring has not been encapsulated in the cavity. Some peaks attributed to the three cycles in the aromatic structure disappear in BFZ complexes formed with $\beta-\mathrm{CD}$, which indicates that a part of the aromatic rings was encapsulated (Fig. 3).

The disappearance of characteristic frequencies of the imidazole ring from the absorption spectra of the complexes in the range of 1000-650 $\mathrm{cm}^{-1}$ indicates that it entered the ring cavity of the HP- $\beta$-CD. Together with the imidazole ring, the aliphatic carbon atom bonded to the $\mathrm{N}$ of the imidazole and a part of the close aromatic cycle was also encapsulated (Fig. 4).
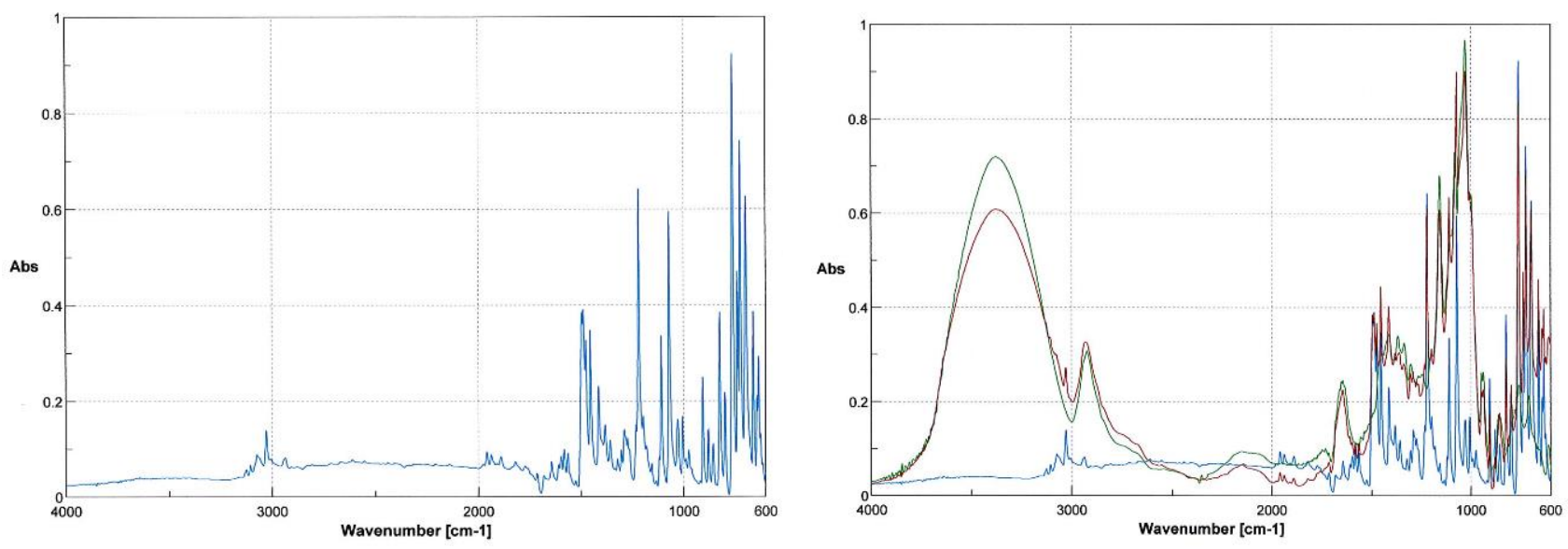

Fig. 3. FTIR spectra of BFZ (left) and $\beta$-CD complex (right).

(BFZ is marked in blue, $\beta-\mathrm{CD}$ in green, and the complex in red.) 

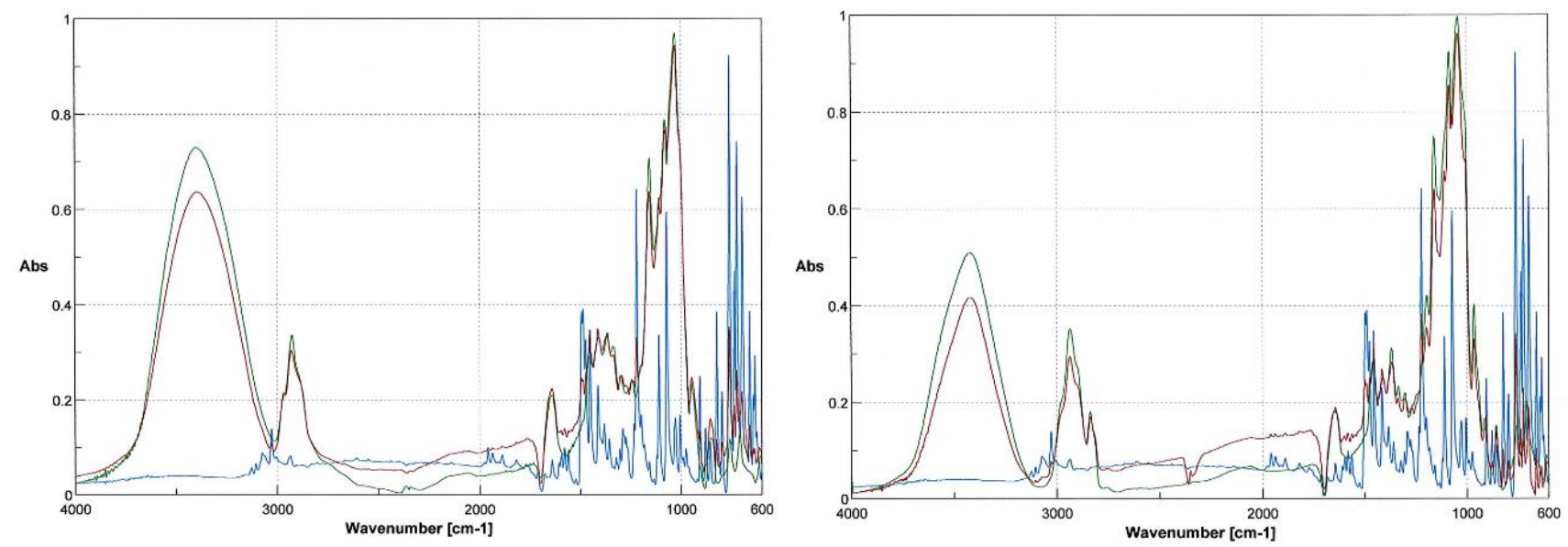

Fig. 4. FTIR spectra of BFZ complexes with HP- $\beta-C D(l e f t)$ and with RAMEB (right). (BFZ is marked in blue, $\mathrm{CD}$ in green, and the complex in red.)
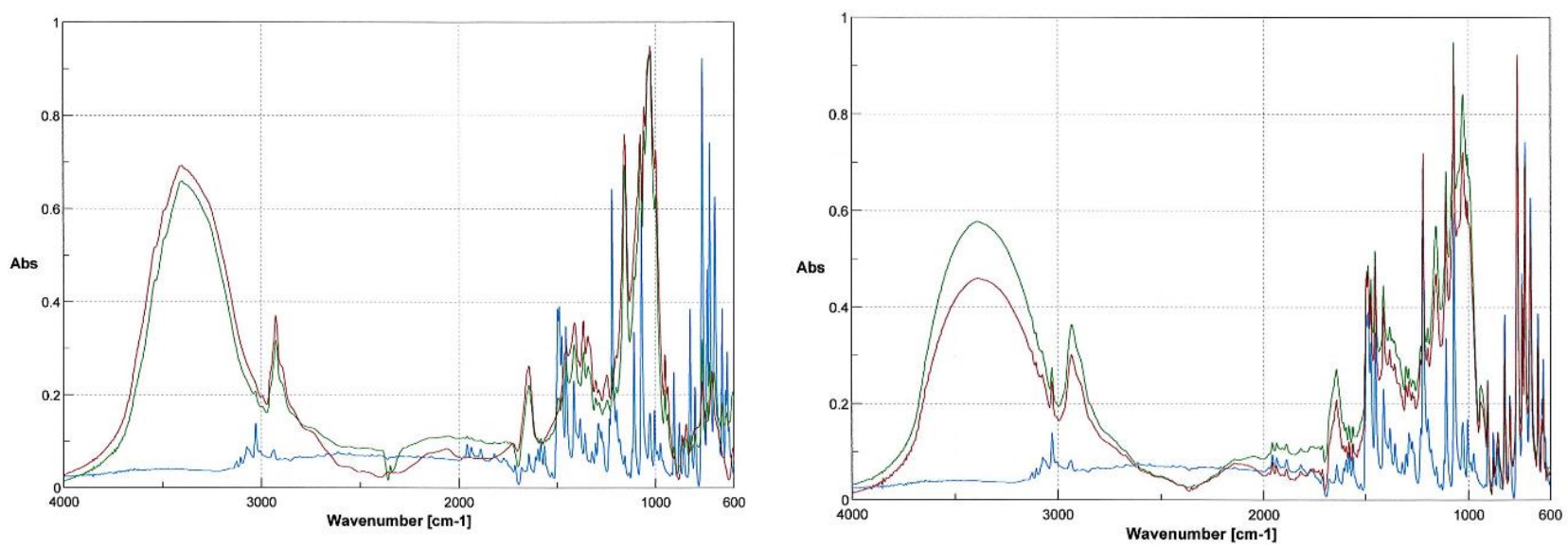

Fig. 5. FTIR spectra of BFZ complexes with $\alpha$-CD (left) and with $\gamma-\mathrm{CD}(r i g h t)$.

(BFZ is marked in blue, $\mathrm{CD}$ in green, and the complex in red.)

For the binary systems, the $1600-600 \mathrm{~cm}^{-1}$ domain was chosen to highlight the modification of spectra due to complexation. The presence of the imidazole ring in the frequency characteristics of the absorption spectrum of BFZ- $\gamma$-CD complex indicates that this ring has not been encapsulated in the cavity. The peaks attributed to the three aromatic cycles disappear from the complexes formed with BFZ and $\gamma-\mathrm{CD}$, indicating that a part of the aromatic rings was encapsulated (Fig. 5).
More evidence of complex formation was obtained by FTIR spectroscopic investigation of the bands corresponding to the functional groups of BFZ involved in the complexation.

\subsection{NMR assignments of $B F Z$}

The assignment of the signals was based on chemical shifts by $2 \mathrm{D}{ }^{1} \mathrm{H}-{ }^{13} \mathrm{C}$ HSQC and HMBC measurements. The values are listed in Table 1 .

Table 1

${ }^{1} H$ chemical shifts of $B F Z$

\begin{tabular}{cccccccccccc}
\hline \hline Nucleus & H-1 & H-2 & H-3 & H-4 & H-5,9 & H-6,8,7 & H-10,18 & H-11,17 & H-12,16 & H-13,15 & H-14 \\
\hline $\boldsymbol{\delta}$ (ppm) & \multirow{2}{*}{8.38} & 7.56 & \multirow{2}{*}{7.48} & 6.84 & 7.13 & 7.32 & 7.16 & 7.53 & 7.34 & 7.49 & 7.28 \\
\hline \hline
\end{tabular}




\subsection{Stability of the complexes}

The observed chemical shift of a specified nucleus is the weighted average of the non- complexed and complexed forms:

$$
\delta^{\mathrm{obs}}=\delta_{\mathrm{BFZ}} \chi_{\mathrm{BFZ}}+\delta_{\mathrm{BFZ}-\mathrm{CD}} \chi_{\mathrm{BFZ}-\mathrm{CD}}
$$

The molar fractions can be expressed by the formula for the stability constant:

$$
K=\frac{[B F Z-C D]}{[B F Z][C D]}
$$

where [BFZ - CD], [BFZ], and [CD] are the equilibrium concentrations of the complex, BFZ, and $\mathrm{CD}$, respectively. None of the equilibrium concentrations can be measured directly; only the analytical concentrations $\left([\mathrm{BFZ}]_{\mathrm{T}}\right.$ and $\left.[\mathrm{CD}]_{\mathrm{T}}\right)$ are known values. Since the analytical concentrations are:

$$
\begin{aligned}
& {[B F Z]_{T}=[B F Z]+[B F Z-C D]} \\
& {[C D]_{T}=[C D]+[B F Z-C D]}
\end{aligned}
$$

the concentration of the complex can be expressed by the analytical concentrations of BFZ and CD by introducing the terms and rearranging Eq. (3):

$$
[B F Z-C D]=\frac{[B F Z]_{T}+[C D]_{T}+\frac{1}{K}-\sqrt{\left([B F Z]_{T}+[C D]_{T}+\frac{1}{K}\right)^{2}-4[B F Z]_{T}[C D]_{T}}}{2}
$$

The molar fractions of the free and complexed BFZ are:

$$
\begin{aligned}
& \chi_{\mathrm{BFZ}}=\frac{[\mathrm{BFZ}]_{\mathrm{T}}-[\mathrm{BFZ}-\mathrm{CD}]}{[\mathrm{BFZ}]_{\mathrm{T}}} \\
& \chi_{\mathrm{BFZ}-\mathrm{CD}}=\frac{[\mathrm{BFZ}-\mathrm{CD}]}{[\mathrm{BFZ}]_{\mathrm{T}}}
\end{aligned}
$$

Combining Eqs. (2), (6) and (7), the observed chemical shift of a given nucleus can be expressed using the analytical concentrations of BFZ and CD:

$$
\delta^{o b s}=\delta_{B F Z}+\Delta \delta \frac{[B F Z]_{T}+[C D]_{T}+\frac{1}{K} \sqrt{\left([B F Z]_{T}+[C D]_{T}+\frac{1}{K}\right)^{2}-4[B F Z]_{T}[C D]_{T}}}{2[B F Z]_{T}}
$$

where $\quad \Delta \delta=\delta_{\mathrm{BFZ}-\mathrm{CD}}-\delta_{\mathrm{BFZ}}$.

Since the $[\mathrm{BFZ}]_{\mathrm{T}}$ was kept constant during the titration, the stability constant and the chemical shifts were calculated by nonlinear parameter fitting of Eq. (8) to the $\delta^{\text {obs }}$ versus $[C D]_{T}$ datasets. The values of stability constants, expressed in $\log \mathrm{K}$, for the CDs are listed in Table2.

Table 2

Stability constants for the inclusion complexes of BFZ in $\log K$ units

\begin{tabular}{cccccccccccc}
\hline \hline & 1 & 2 & 3 & 4 & 5 & 6 & 7 & 8 & 9 & 10 \\
\hline \multirow{2}{*}{$\mathbf{C D}$} & $\beta-\mathrm{CD}$ & $\gamma$-CD & $\begin{array}{c}\text { RAME- } \alpha- \\
\text { CD }\end{array}$ & $\begin{array}{c}\text { RAME- } \beta- \\
\text { CD }\end{array}$ & $\begin{array}{c}\text { RAME- } \gamma- \\
\text { CD }\end{array}$ & $\begin{array}{c}\text { HP- } \beta- \\
\text { CD }\end{array}$ & $\begin{array}{c}\text { HP- } \gamma \text { - } \\
\text { CD }\end{array}$ & $\begin{array}{c}\text { SBE- } \\
\alpha-C D\end{array}$ & $\begin{array}{c}\text { SBE- } \\
\beta-C D\end{array}$ & S- $\beta$-CD \\
\hline $\operatorname{logK}$ & 3,57 & 6,45 & 1,98 & 3,43 & 4,23 & 3,66 & 6,23 & 3,59 & 3,94 & 3,11 \\
\pm & 0,02 & 0,07 & 1,37 & 0,02 & 1,38 & 0,02 & 0,02 & 0,54 & 0,05 & 0,02 \\
\hline \hline
\end{tabular}

In the case of the complexes BFZ:HP- $\gamma-\mathrm{CD}$ and BFZ: $\gamma-\mathrm{CD}$, we can observe that the values of the stability constants are approximately double the other values, which indicates the presence of an- 
other type of inclusion complex with these two CDs, with a stoichiometry of $2: 1$. This theory was confirmed by other methods too.

\subsubsection{Stoichiometry of the inclusion complexes}

The stoichiometry of the CD complexes was determined by the continuous variation method of Job [21], where the chemical shift changes $(\Delta \delta)$ weighted by the molar fraction of BFZ were plotted depending on the molar fraction of BFZ.

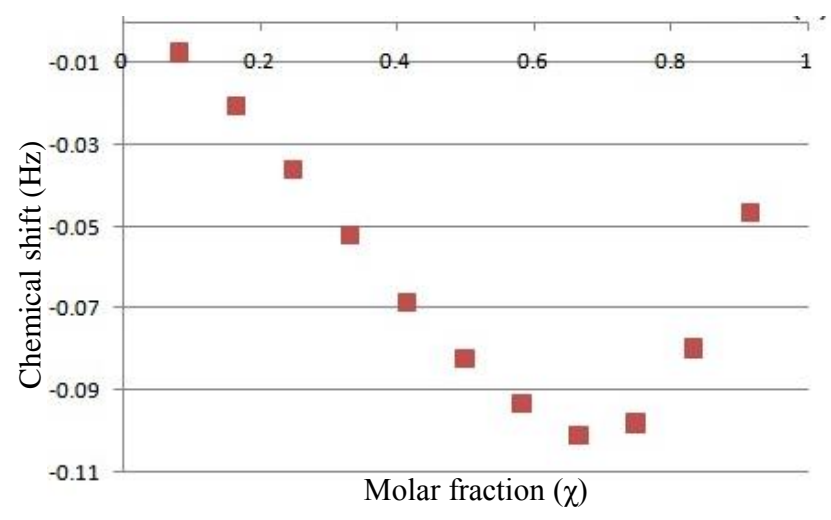

Fig. 6. Job's plot of selected BFZ proton in the complex of BFZ- $\gamma-C D$
The maxima of the chemical shifts of the complexes occur when the molar fraction is 0.5 , indicating 1:1 stoichiometry for the complexes, which is the most common form of CD complex. Another type of complex appears with $\gamma-C D$, where the maxima of the chemical shifts of the complexes occur when the molar fraction is 0.6, which indicates a stoichiometry of 2:1 (Fig. 6).

\subsubsection{Structure of the inclusion complexes}

The structures of the inclusion complexes were investigated for BFZ with two CDs: $\beta-C D$ and $\gamma-\mathrm{CD}$, by the $2 \mathrm{D}{ }^{1} \mathrm{H}-{ }^{1} \mathrm{H}$ COSY method. There were clear cross-peaks between $H-5,9$ (7.23 ppm) and $H$ $6,8(7.38 \mathrm{ppm})$ protons of $\mathrm{BFZ}$ and the protons (3.58 and $3.68 \mathrm{ppm})$ of $\beta-\mathrm{CD}$, which indicates that the phenyl ring of BFZ stays in the CD cavity (Fig. 7).

In the complex of BFZ: $\gamma-C D$ with a stoichiometry of $2: 1$, the biphenyl ring stays inthe cavity (Fig. 8). This fact is demonstrated by the clear cross-peaks between the protons of the CD (3.25 ppm, $3.37 \mathrm{ppm}$ ) and the protons of BFZ from the biphenyl ring $(H-10,18: 7.21 \mathrm{ppm} ; H-12,16: 7.26$ ppm) (Fig. 9).

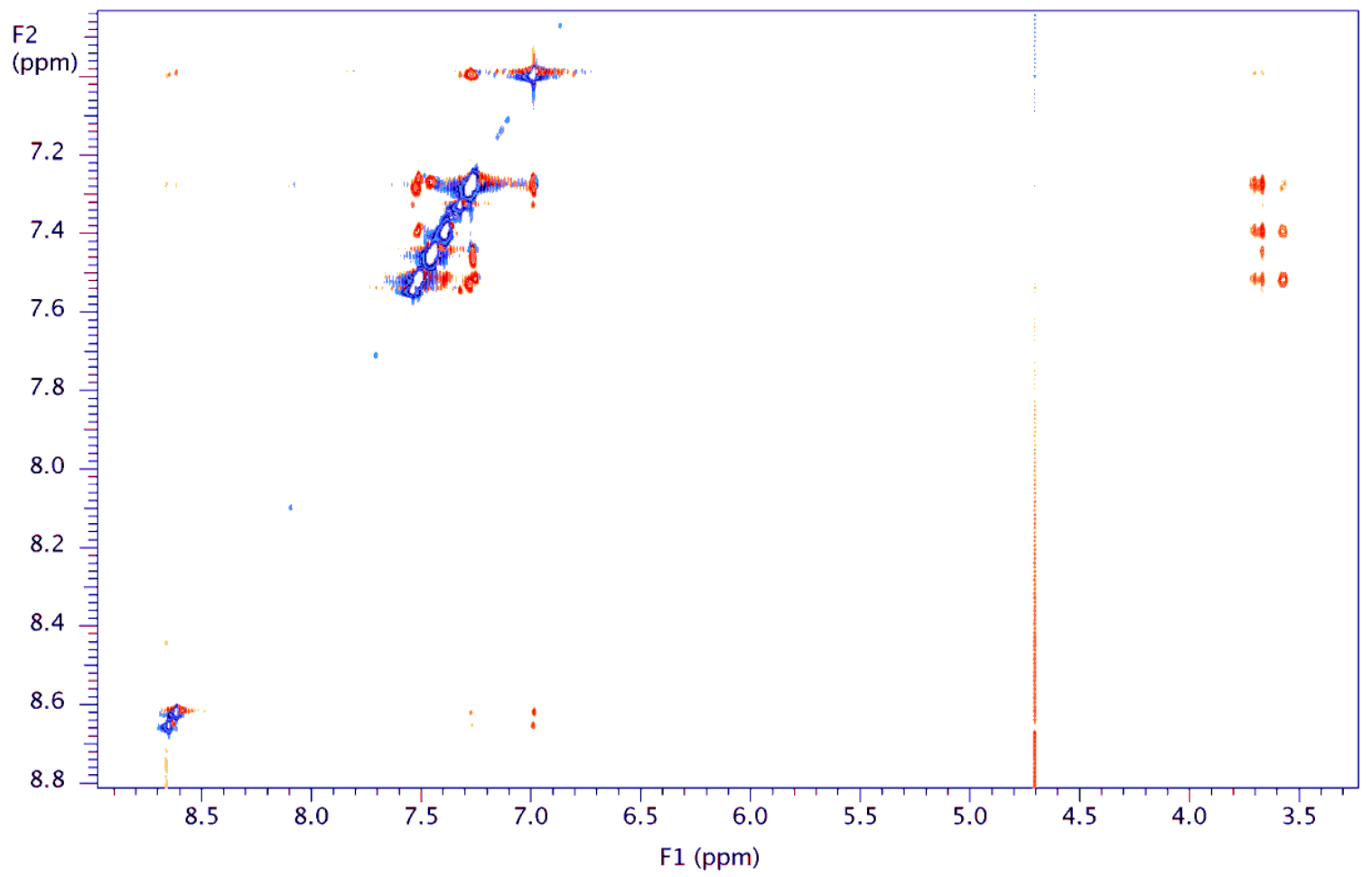

Fig. 7. Part of the ${ }^{1} \mathrm{H}-{ }^{1} \mathrm{H}$ COSY spectrum of the complex of BFZ- $\beta-\mathrm{CD}$ 

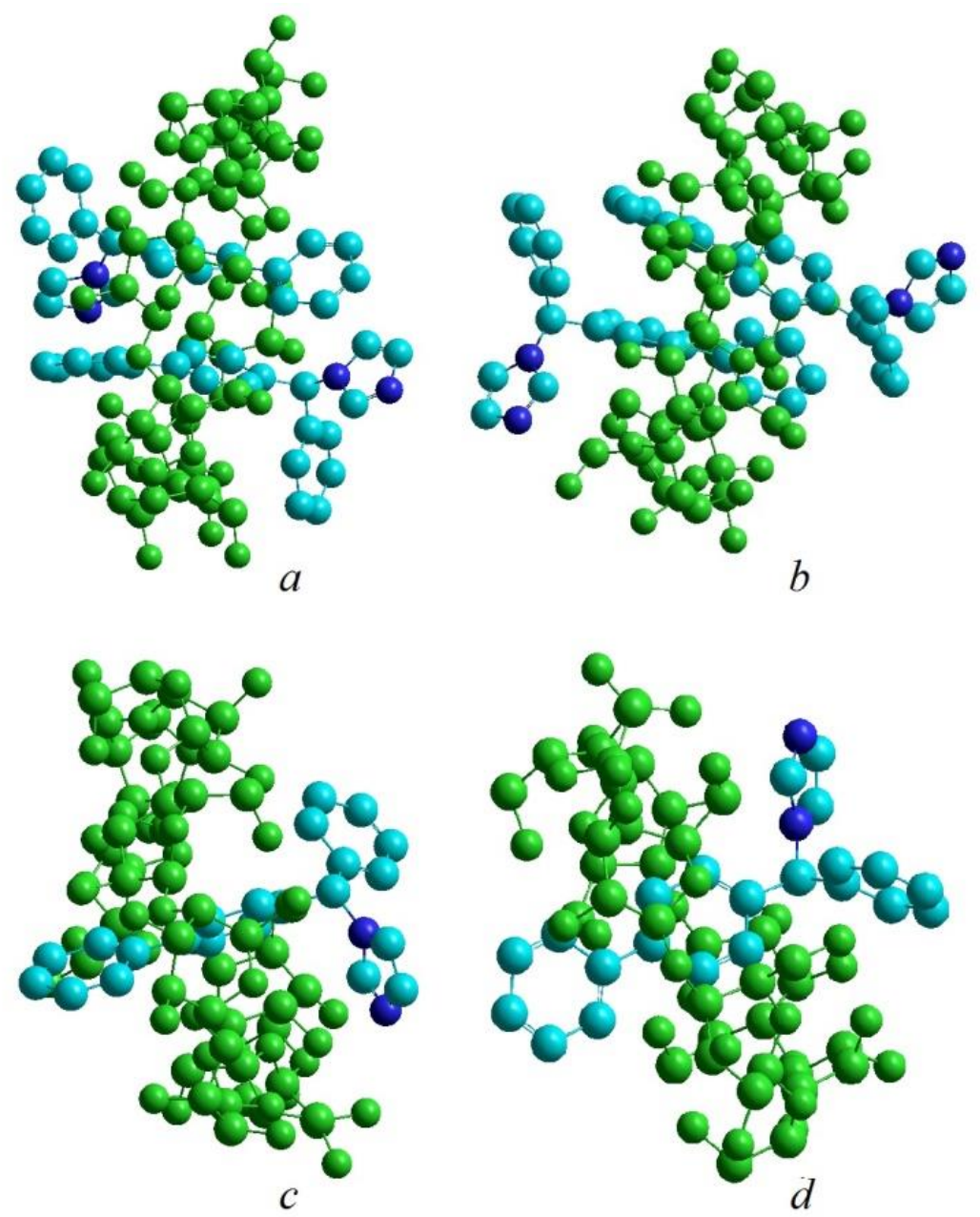

Fig. 8. Molecular modeling representation of the BFZ- $\gamma$-CD 2:1 (a); BFZ- $\beta$-CD 2:1 (b); BFZ- $\gamma$-CD 1:1 (c); and BFZ- $\alpha$-CD 1:1 (d) complexes. (Green: $\gamma$-CD; light blue: carbon; dark blue: nitrogen.)

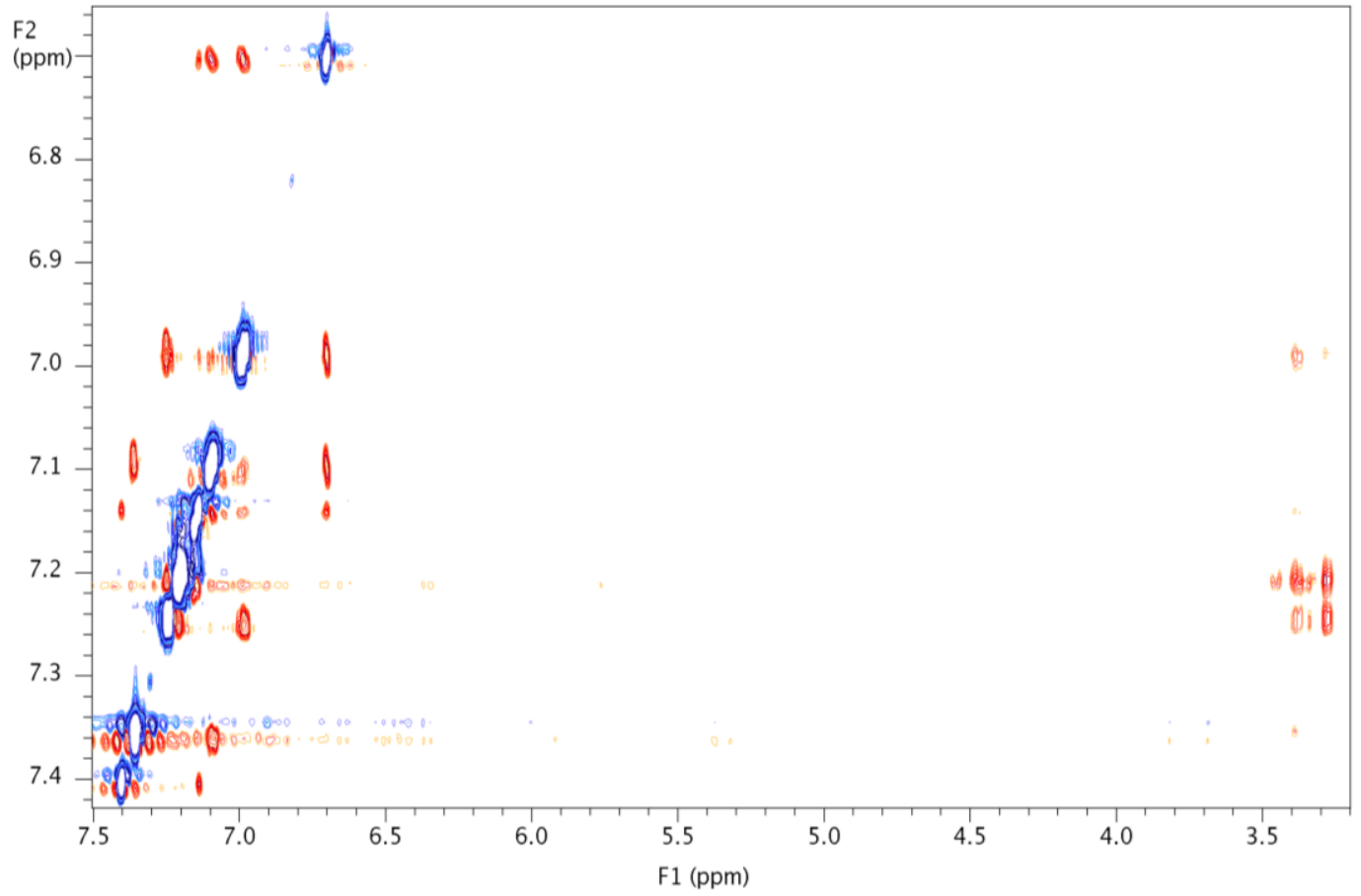

Fig. 9. Part of the ${ }^{1} \mathrm{H}-{ }^{1} \mathrm{H}$ COSY spectrum of the complex of BFZ- $\gamma$-CD 


\subsection{Molecular modeling studies}

Based on the values of the formation energies, the most stable complex is formed in the case of $\gamma-\mathrm{CD}$, when two molecules of BFZ are inserted into the cavity of the $\mathrm{CD}$.

The energy minimized structure of the BFZ: $\gamma$-CD 2:1 complex is shown in Figure 8.

The highest formation energies were -17.86 , $-12.79,-10.90,-10.75$, and $-4,64 \mathrm{kcal} / \mathrm{mol}$ in the cases of BFZ- $\gamma$-CD 2:1, BFZ- $\beta$-CD 2:1, BFZ- $\beta$-CD $1: 1, \mathrm{BFZ}-\gamma-\mathrm{CD} 1: 1$, and BFZ- $\alpha-\mathrm{CD} 1: 1$, respectively, indicating that BFZ complexes of the natural CDs are more stable than those of the chemically modified CDs. The energy minimized structures of these complexes are shown in Figure 8 (hydrogen depleted structure).

\section{CONCLUSIONS}

This study demonstrated the establishment of favorable molecular interaction between the BFZ and the CDs in both solid state and solution. It was revealed that the properties of the products of CDs with BFZ are influenced by the nature of the $\mathrm{CD}$.

Changes in the FTIR spectra such as a shift of the characteristic absorption bands of BFZ, the disappearance or reduction of intensity, and the appearance of new bands might be related to possible drug-CD interactions.

The DSC analysis supports the hypothesis of the formation of partial inclusion complexes between BFZ and most of the studied CDs; furthermore, for $\gamma-\mathrm{CD}$ or HP- $\beta-\mathrm{CD}$, the complexation proved to be total.

The stoichiometry of the inclusion complexes depends on the size of the CD cavity. With the $\alpha$ and $\beta$-CDs, BFZ : CD complexes have a 1:1 stoichiometry, whereas with $\gamma-\mathrm{CD}, \mathrm{BFZ}$ : CD complexes present a 2:1 stoichiometry; the BFZ : $\gamma$-CD complexes exhibited very high stability constants.

These data can be utilized for improved BFZ drug formulations.

Acknowledgments. This work was supported by the Transylvanian Museum Society and Semmelweis University, Faculty of Pharmacy research grant no. 128./P.2. EMEOGYSZ 2014.

\section{REFERENCES}

[1] T. E. Lackner, S. P. Clissold, Bifonazole. A Review of its antimicrobial activity and therapeutic use in superficial mycoses, Drugs, 38 (2), 204-225 (1989).
[2] D. Berg, K. H. Büchel, M. Plempel, E. Regel, Antimycotic sterol biosynthesis inhibitors, Trends in Pharmacology Sciences, 7, 233-238 (1986).

DOI: 10.1016/0165-6147(86)90330-5

[3] H. Petri, H. Tronnier, P. Haas, Investigations into the anti-inflammatory effect of bifonazole, In: Hay R. J. (ed.). Advances in Topical Antifungal Therapy, Springer Verlag, Berlin, 26-31, 1986.

[4] L. Hegemann, S. M. Toso, K. I. Lahijani, G. F. Webster, J. Ditto, Direct interaction of antifungal azolederivatives with calmodulin: a possible mechanism for their therapeutic activity, Journal of Investigative Dermatology, 100 (3), 343-346 (1993).

DOI: $10.1111 / 1523-1747 . e p 12470043$

[5] A. P. Tiziani, Havard's Nursing Guide to Drugs, Elsevier Health Sciences, 2010.

[6] http://pubchem.ncbi.nlm.nih.gov/compound/2378\#sectio $\mathrm{n}=$ Computed-Properties

[7] J. T. Lalwani, V. T Thakkar, H. V. Patel, Enhancement of solubility and oral bioavailability of ezetimibe by a novel solid self nano-emulsifying drug delivery system (SNEDDS), International Journal of Pharmacy and Pharmaceutical Sciences, 5 (3), 513-522 (2013).

[8] K. S. G. Arulkumaran, J. Padmapreetha, Enhancement of solubility of ezetimibe by liquisolid technique, International Journal of Pharmaceutical Chemistry and Analysis, 1 (1), 14-38 (2014).

[9] L. Zerkoune, S. Lesieur, J. L. Putaux, L. Choisnard, A. Geze, D. Wouessidjewe, B. Angelov, C. Verbert-Nardin, J. Doutch, A. Angelova, Mesoporous self-assembled nanoparticles of biotransesterified cyclodextrins and nonlamellar lipids as carriers of water-insoluble substance, Soft Matter, 12, 7359-7350 (2016). DOI: $10.1039 / \mathrm{c} 6 \mathrm{sm} 00661 \mathrm{~b}$

[10] L. Zerkoune, A. Angelova, S. Lesieur, Nano-assemblies of modified cyclodextrins and their complexes with guest molecules: incorporation in nanostructured membranes and amphiphilenanoarchitectonics design, Nanomaterials, 4 (3), 741-765 (2014).

DOI: $10.3390 /$ nano4030741

[11] A. Angelova, B. Angelov, R. Mutafchieva, S. Lesieur, Biocompatible mesoporous and soft nanoarchitectures, Journal of Inorganic and Organometalic Polymers., 25, 214-232 (2015). DOI:10.1007/s10904-014-0143-8

[12] A. Angelova, C. Fajolles, C. Hocquelet, F. DejedainiPilard, S. Lesieur, V. Bonet, B. Perly, G. Lebas, L. Mauclaire, Physico-chemical investigation of asymmetrical peptidolipidyl-cyclodextrin, Journal of Colloid Interface Science, 322, 304-314 (2008).

DOI: $10.1016 /$ j.jcis.2008.03.023

[13] T. Loftsson, D. Duchene, Cyclodextrins and their pharmaceutical applications, International Journal of Pharmaceutics, 329, 1-11 (2007). DOI: 10.1016/j.ijpharm.2006.10.044

[14] T. Loftsson, B. J. Ólafsdóttir, H. Fridriksdottir, S. Jonsdottir, Cyclodextrin complexation of NSAIDs: physicochemical characteristics, European Journal of Pharmaceutical Sciences, 1 (2), 95-101(1993).

[15] E. M. Dell Valle, Cyclodextrins and their uses: A review, Process Biochemistry, 39, 1033-1046 (2004). DOI: $10.1016 / \mathrm{S} 0032-9592(03) 00258-9$ 
[16] J. Szejtli, The cyclodextrins and their applications in biotechnology, Carbohydrate Polymers, 12, 375-392 (1990).

[17] A. Angelova, C. Ringard-Lefebvre, A. Baszkin, Drugcyclodextrin association constants determined by surface tension and surface pressure measurements. I. Hostguest complexation of water soluble drugs by cyclodextrins: polymyxin B - beta-cyclodextrin system, Journal of Colloid Interface Science, 212, 275-279 (1999). DOI: $10.1006 /$ jcis.1999.6088

[18] A. Angelova, C. Ringard-Lefebvre, A. Baszkin, Drugcyclodextrin association constants determined by surface tension and surface pressure measurements. II. Sequestration of water insoluble drugs from the air/water interface: Retinol beta-cyclodextrin system, Journal of Colloid Interface Science, 212, 280-285 (1999). DOI: $10.1006 /$ jcis. 1999.6089

[19] P. J. Mura, Analytical techniques for characterization of cyclodextrin complexes in the solid state: A review. Journal of Pharmaceutical and Biomedical Analysis, 113, 226-238 (2015). DOI: $10.1016 / j . j p b a .2015 .01 .058$

[20] G. Yurtdas, M. Demirel, L. Genc, Inclusion complexes of fluconazole with $\beta$-cyclodextrin: physicochemical characterization and in vitro evaluation of its formulation, Journal of Inclusion Phenomena and Macrocyclic Chemistry, 70 (3-4), 429-435 (2011). DOI: $10.1007 / \mathrm{s} 10847-010-9908-\mathrm{Z}$

[21] C. Trandafirescu, A. Gyeresi, Z. Szabadai, M. Kata, Z. Aigner, Solid-state characterization of bifonazole-betacyclodextrinbinary systems. Note I., Farmacia, 62 (3), 513-523 (2014).

[22] R. Singh, N. Bharti, J. Madan, S. N. Hiremath, Characterization of cyclodextrin inclusion complexes. A review, Journal of Pharmaceutical Science and Technology, 2 (3), 171-183 (2010).

[23] G. Orgován, H. Kelemen, B. Noszál, Protonation and $\beta$ cyclodextrin complex formation equilibria of fluconazole, Journal of Inclusion Phenomena and Macrocyclic Chemistry, 84 (3-4), 189-196 (2016).

DOI: $10.1007 / \mathrm{s} 10847-016-0595-2$
[24] J. Li, S. Zhang, Y. Zhou, S. Guan, L. Zhang, Inclusion complexes of fluconazole with $\beta$-cyclodextrin and 2 hydroxypropyl- $\beta$-cyclodextrin in aqueous solution: preparation, characterization and a structural insight, Journal of Inclusion Phenomena and Macrocyclic Chemistry, 84 (3-4), 209-217 (2016). DOI: $10.1007 / \mathrm{s} 10847-010-9908-\mathrm{z}$

[25] G. Popović, M. Čakar, The effects of $\beta$-cyclodextrin and $\mathrm{pH}$ on bifonazole hydrosolubility, Journal of the Serbian Chemical Society, 69 (3), 225-231(2004).

[26] H. Gupta, K. Kar, Solid state compatibility studies of miconazole using thermal and spectroscopic methods, Advances in Analytical Chemistry, 5 (3), 51-55 (2015). DOI: 10.5923/j.aac.20150503.01.

[27] P. Job, Job's method of continuous variation, Ann. Chim., 9, 113-120 (1928).

[28] N. Marangoci, M. Mares, M. Silion, A. Fifere, C. Varganici, A. Nicolescu, C. Deleanu, A. Coroaba, M. Pinteala, B. C. Simionescu, Inclusion complex of a new propiconazole derivative with $\beta$-cyclodextrin: NMR, ESI-MS and preliminary pharmacological studies, Results in Pharma Sciences, 1 (1), 27-37 (2011). DOI: 10.1016/j.rinphs.2011.07.001

[29] J. Szejtli, Cyclodextrins and Their Inclusion Complexes, Akadémiai Kiadó, Budapest, 1982.

[30] P. J. Hore, Nuclear Magnetic Resonance. Oxford University Press, Oxford, 98-101, 1995.

[31] Facchiano, R. Ragone, Modification of Job's method for determining the stoichiometry of protein-protein complexes, Analytical Biochemistry, 313, 170-172 (2003).

[32] S. K. Upadhyay, G. Kumar, NMR and molecular modelling studies on the interaction of fluconazole with $\beta$ cyclodextrin, Chemistry Central Journal, 3 (1), (2009). DOI:10.1186/1752-153X-3-9

[33] S. R. Arsad, H. Maarof, I. W. Wan, H. Y. Aboul-Enein, Theoretical and molecular docking study of ketoconazole on heptakis (2,3,6-tri- $O$-methyl)- $\beta$-cyclodextrin as chiral selector, Chirality, 28 (3), 209-214 (2016). DOI:10.1002/chir.22554 
